\title{
Can employment subsidies and greater labour market flexibility increase job opportunities for youth? Revisiting the Italian On-the-job Training Programme
}

\author{
Giuseppe Tattara $\cdot$ Marco Valentini
}

Accepted: 29 April 2009 / Published online: 4 July 2009

(C) Institut für Arbeitsmarkt- und Berufsforschung 2009

\begin{abstract}
The CFL (On-the-job Training) Programme was introduced in Italy in 1985 with the aim of reducing youth unemployment. The new programme offered employers two main advantages: it exempted them almost completely from payment of payroll taxes and it provided them with virtually the only opportunity to employ people on a basis of fixedterm contracts.

The paper looks at the employment impact of the programme among a subgroup of eligible workers in the north Italian provinces of Treviso and Vicenza and finds that firms taking part increased employment more than non-participating firms by almost 5\%. Employers had a strong positive reaction to the tax subsidies and to the softening of the rigid employment code.

The overall effect of the programme on youth employment in Treviso and Vicenza was however limited, register-

This research has been financed by the Prin-Miur 2003 programme No. 2003139334 Metodi e studi di valutazione degli effetti di politiche del lavoro, di aiuto alle imprese e di welfare. Part of the research was carried out during a visit by M. Valentini to the IFS, London, in 2003. The paper has been discussed at the AIEL 2004 annual conference, "Social Pacts, Employment and Growth: A Reappraisal of the Thoughts of Ezio Tarantelli"; at the IAB 2005 conference "The Empirical Evaluation of Labour Market Programmes"; at the Bank of Italy 2005 economic seminars; and at the workshop "The Evaluation of Labour Market, Welfare and Firm Incentive Programmes", Prin 2006. We thank all participants for helpful discussions. Particular thanks go to Federico Cingano, Piero Cipollone, Frank Pyke, Enrico Rettore and Barbara Sianesi for their comments and suggestions.
\end{abstract}

G. Tattara ( )

University of Venice, Department of Economics,

Cannaregio 873, 30121 Venice, Italy

e-mail: tattara@unive.it

M. Valentini

Tolomeo srl.,

Treviso, Italy ing only a $1 \%$ increase, mainly because about $80 \%$ of firms never participated.

Können Lohnkostenzuschüsse und eine größere Flexibilität des Arbeitsmarktes die Anzahl der Stellenangebote für Jugendliche erhöhen? Eine Neuerwägung des italienischen Betriebsausbildungsprogramms

Zusammenfassung Das CFL-Programm (Betriebsausbildungsprogramm) wurde 1985 mit dem Ziel, die Jugendarbeitslosigkeit zu reduzieren, in Italien eingeführt. Das neue Programm bot Arbeitgebern zwei große Vorteile: es befreite sie fast gänzlich von Lohnsteuerzahlungen und bot ihnen praktisch die einzige Möglichkeit, Arbeitnehmer auf Basis befristeter Verträge einzustellen.

Die Abhandlung beleuchtet die Auswirkungen des Programms auf das Beschäftigungsverhältnis anhand einer Untergruppe geeigneter Arbeiter in den norditalienischen Provinzen Treviso und Vicenza und stellte fest, dass an dem Programm teilnehmende Firmen die Anzahl der Arbeitsplätze um fast $5 \%$ erhöhten im Vergleich zu Firmen, die nicht daran teilnahmen. Die Arbeitgeber zeigten eine stark positive Reaktion auf den Lohnkostenzuschuss und die Lockerung der streng reglementierten Einstellungsgesetze.

Der Auswirkung des Programms auf die Jugendarbeit in Treviso und Vicenza war im Allgemeinen jedoch begrenzt. Die Anzahl der Einstellungen stieg nur um 1\%, vor allem, weil etwa $80 \%$ der Firmen nicht am Programm teilnahmen.

\section{Introduction}

The CFL, On-the-Job Training Programme (Contratto di Formazione e Lavoro), was a scheme designed to integrate 
more young people into employment. It was typical of what was happening in many European countries after the mid seventies when there was an increase in policies aiming to promote youth employment through active labour market policies (ALMP) at a time of very high levels of unemployment. (O’Higgins 1997, p. 54; Blanchard 2006; Saint-Paul 2004).

The schemes have varied somewhat in form and content over the years and for different countries, but are generally characterised by the use of two basic mechanisms 1) increasing the skill levels of young workers through training 2) lowering labour costs, by reducing wage expectations, and/or reducing the cost of hiring, and/or increasing flexibility for targeted groups of workers, particularly in countries with rigid labour markets. High payroll taxes and over protective labour legislation are frequently asserted to be two of the main causes of the high rates of unemployment experienced in Europe in recent decades (OECD 2006).

In the eighties, the Italian labour market was characterised by strong protection regulation and a rigid system of wage determination. The Charter of Workers' Rights (Statuto dei lavoratori) had established various employment restrictions (in firms with more than 15 employees) on hiring and firing procedures, and on the use of temporary labour contracts. Also, a minimum wage, generally laid down in sectoral agreements, had been collectively agreed, and applied to all workers, with an almost total coverage.

The CFL programme was introduced in Italy in the last month of 1984 in an attempt to tackle youth unemployment (eligible participants should be less than 29 years old). The new contract had two major advantages: it exempted employers (almost completely) from the payment of payroll taxes, and it was virtually the only form of fixed-term contract available for use. The contract provided a partial reform of existing employment protection legislation, introducing an automatic termination after a maximum of two years, and a wage subsidy (as well as reduced taxes) that might ease the distortions caused by the minimum wage legislation (Nikell and Bell 1997).

Several papers have found that this type of partial reform is inefficient (Blanchard and Landier 2002). In particular, it has been claimed that it induces firms to replace high cost workers with low cost workers, and encourages high turnover and a reduction in skill levels, and that this can lead to a waste of know-how and intellectual resources.

On the whole, the impact of programmes targeted at young workers in Europe has been mixed. Training programmes in particular have had poor results. However, wage subsidies and tax reductions have provided more encouraging findings, but have been accompanied by potential displacement and substitution effects that have seldom been taken properly into account (Kluve and Schmidt 2002; ILO 2005; Kluve 2006).
By considering the introduction of the CFL programme as an exogenous innovation, this paper evaluates its employment impact on a subgroup of eligible workers, those aged 21-29, in two provinces in the North Eastern part of Italy (Treviso and Vicenza). The experiences there are politically relevant as they show that the programme was conducive to job creation net of possible substitution and displacement effects. Firms participating in the programme increased their employment of eligible workers more than did non-participants by almost 5\%, although the overall impact in the provinces was small, producing about a one per cent employment increase, because only one-fourth of firms participated.

This paper is structured in the following manner. Section 2 describes the CFL programme, its initial structure and subsequent changes. Section 3 sets out the evaluation problem to be addressed, formulates the micro-econometric analysis and describes a matching approach. Section 4 presents the empirical results, and a set of sensitivity analyses to assess the robustness of the estimated employment effects. This section also devotes particular attention to exploring the linkages between treatment effects, substitution possibilities and different workers' abilities. Section 5 describes CFL reforms that occurred and discusses the programme's lasting consequences. Section 6 examines the causes for the programme's limited diffusion and provides some suggestions for formulating active labour market programmes in Europe today, and then concludes.

\section{The CFL programme}

The CFL was a fixed-term contract introduced at the end of 1984 in order to facilitate the engagement of young workers in the labour market. The CFL programme was aimed at public and private firms hiring young people aged between 15 and 29 years, and which at the date of application had no recent record of mass redundancies. The programme included the provision of training under a scheme endorsed by the Regional Commission for Employment. ${ }^{1}$

The CFL contained a number of benefits. First of all, Social Security contributions paid by participating Italian firms were reduced to 2.5 Euros per capita, a substantial reduction, as the payroll tax in Italy amounted to around $40 \%$ of a person's salary, and was one of the largest taxes of its kind in Europe (Contini 2000). Further, the participants were exempted from the usual firing costs associated with the widely used alternative of the open-ended contract, while the 24-month "fixed-term" duration of the CFL allowed a signif-

\footnotetext{
${ }^{1}$ The training would subsequently turn out to have been largely ineffective, as shown by several studies. (Breda 1993, p. 167).
} 
icant increase in flexibility. ${ }^{2}$ The programme offered workers specific on-the-job training so that those hired through the CFL were expected to develop a stable and qualified career with the firm. The firm was allowed to hire a worker at a lower contract level (two grades down) than would normally be proscribed by his/her qualifications according to the national contract. Entrepreneurs were also able to hire workers directly, without applying to the Italian Ufficio di Collocamento (employment office), ${ }^{3}$ which was the usual practice and which meant hiring from a pool of declared unemployed, basically on a first-come first-served basis. In 1991, the opportunity to engage in direct hiring was extended to all Italian firms and one of the comparative advantages of the programme was lost.

At the beginning, workers eligible for employment in enterprises under the CFL programme were young people aged between 15 and 29 years. ${ }^{4}$ In 1994, the eligible age range was changed to between 16 and 32 years and eligible workers were extended to include self-employed professionals and workers hired by associations and by research centres. ${ }^{5}$ The range of eligible workers was thus extended over the years in response to demand, but at the same time the financial benefits connected to the contract were progressively reduced. The payroll tax rebate was reduced from $98 \%$ to $50 \%$ and subsequently to $25 \% .^{6}$ From 1991 , firms applying to the programme, and that had participated in the past, were required to have hired at least $50 \%$ of the employees that had come to the end of their CFL programme over the previous two years. This percentage rose to $60 \%$ in $1994 .^{7}$ CFL terminated in 1995 (Table 1). ${ }^{8}$

\footnotetext{
${ }^{2}$ Fixed-term contracts were introduced in Italy in 1962 , but were very strictly limited (covering seasonal activities and temporary replacements). CFL was the first widely diffused fixed-term contract. It could not be renewed with the same training specification. In fact, the contract was seldom renewed.

${ }^{3}$ With exceptional conditions for apprentices (Law No. 25, 19. January 1955 art. 3).

${ }^{4}$ The upper boundary was 32 years old for the South of Italy and also for those Northern Italian regions with an unemployment rate higher than the national average.

${ }^{5}$ The latter were included by Law No. 196, 24. June 1997. Law No. 299, 16. May 1994 added a new second type of job training contract to the previous one. It offered a reduced training period of 12 months, and allowed employers to be eligible for the tax rebate for one year after the CFL contract was transformed into a permanent contract. Employers undertaking the 12 month CFL were eligible for the rebate only if the contract was transformed.

${ }^{6}$ Employers in the southern regions continued to enjoy the full rebate (see Table 1).

${ }^{7}$ The percentage was raised to $60 \%$ in May 1994. D.L. No. 299, 16. May 1994. Lay-offs and firings for misbehaviour (per giusta causa) were not considered when calculating the hiring percentage.

${ }^{8}$ It was declared illegitimate by the European Commission on the grounds of unfair competition because the level of subsidies were differentiated by territory (firms in the Mezzogiorno had higher incentives) and by type of firm. As of today, targeted payroll tax rebates are legitimate only to the ex-
}

The progressive limitation of the incentives attached to the programme resulted from two factors: firstly, the precarious condition of Italian public finances, and secondly an attempt to make the programme more selective, encouraging its use by firms with favourable employment prospects while discouraging firms that were only interested in the financial bonus (Contini et al. 2002).

The present study is based on VWH (Veneto Worker Histories), a data-set built up at the University of Venice from social security files. VWH contains information on all participants in the CFL programme in the private sector in the two provinces of Treviso and Vicenza, for the years 1975-1997. It includes register-based information on all establishments in the two provinces, and on all the employees that were hired by those establishments - even if for just one day during the observation period - independent of the worker's place of residence. ${ }^{9}$ The observation unit is the employer-day and is used to build a monthly history of the working life of each employee. The choice of location was constrained by data availability, but the two provinces make an interesting case study because of the wide diffusion of the scheme there.

The paper focuses on young workers of 21 to 29 years of age. For workers aged 21 to 29 , the CFL was the only alternative available to the "normal" open-ended contract, and so its impact can be more accurately measured. The selected group is split into two to take into account different characteristics. A 21-24 cohort includes workers that had finished high school or military service (if males). A 25-29 cohort includes workers with a college education, and also workers with higher skills and work experience. Younger workers aged 16 to 20 are not considered because they could take advantage of two "entry contracts", the CFL and the apprentice contract, the effects of which overlapped and this makes identification of the CFL impact difficult.

After 1985, when CFL was launched, the programme was immediately and unquestionably successful. For many firms, particularly small firms, CFL became a common way to hire young people. In Italy, on average about $25 \%$ of hiring in the eligible age cohorts was through the programme. In Treviso and Vicenza, workers hired under the programme were almost $15 \%$ of the eligible employment stock in December 1987, rising to $24 \%$ for those aged 21 to 24 (See Fig. 1). The number of CFL workers continued to increase until the first programme reform in 1988, then a more modest growth in 1989 changed into a drastic decline, especially after the second reform of December

tent that new jobs are created by the same employer, in addition to existing ones.

${ }^{9}$ The entire working life of all employees that worked at least one day in Treviso and Vicenza, was reconstructed, including periods of work away from Treviso and Vicenza (Tattara and Valentini 2004). 
Table 1 CFL Rebate on social security tax payable by employers

\begin{tabular}{lll}
\hline Year & $\begin{array}{l}\text { Employers: } \\
\text { Artisans; Southern Italians; Employers } \\
\text { from high unemployment areas (\%) }\end{array}$ & $\begin{array}{l}\text { All others } \\
(\%)\end{array}$ \\
\hline from 1.11.1984 to 30.5 .1988 & About 98 & About 98 \\
from 1.6.1988 to 29.12.1990 & About 98 & 50 \\
from 1.1.1991 onward-... & About 98 & 25 \\
\hline
\end{tabular}

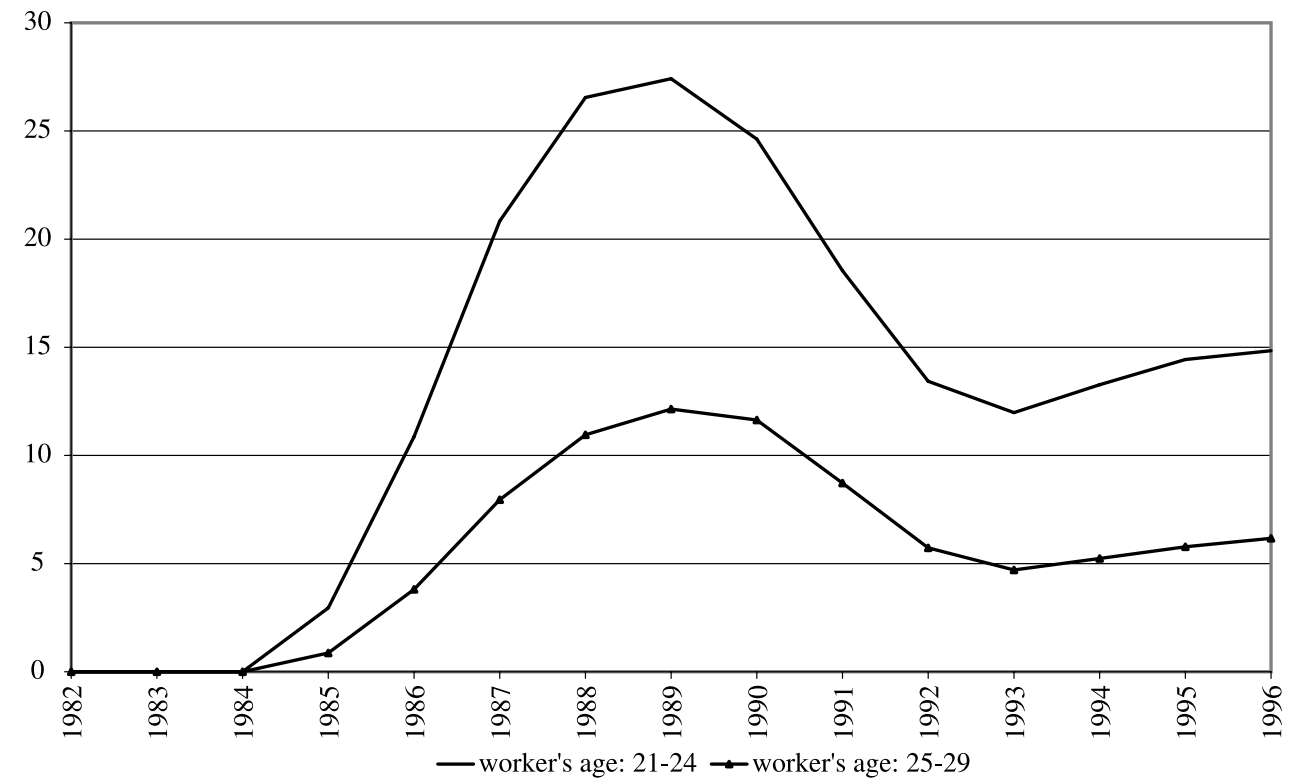

Fig. 1 CFL Workers as a percentage of all eligible workers in vicenza and Treviso provinces

Table 2 The probability of transition from non-employment to employment in Treviso and Vicenza

\begin{tabular}{lllllllll}
\hline Age cohort & 1982 & 1983 & 1984 & 1985 & 1986 & 1987 & 1988 & 1989 \\
\hline $16-20$ & 0.58 & 0.53 & 0.58 & 0.71 & 0.78 & 0.84 & 0.86 & 0.79 \\
$21-24$ & 0.20 & 0.18 & 0.19 & 0.23 & 0.29 & 0.32 & 0.33 & 0.33 \\
$25-29$ & 0.15 & 0.13 & 0.14 & 0.17 & 0.22 & 0.25 & 0.27 & 0.28 \\
$30-32$ & 0.07 & 0.06 & 0.07 & 0.09 & 0.11 & 0.12 & 0.14 & 0.14 \\
\hline
\end{tabular}

The probability of transition from non-employment to employment is computed as the ratio between associations from non-employment into employment (VWH data) and the stock of the active population in the final year (interpolated from the population censuses of 1981 and 1991 according to the employment rate, adjusted to fit the proper age class).
1990; then it increased once again in the mid nineties, in response to a recovering economy.

Table 2 presents the probability of a young worker from Treviso or Vicenza provinces moving from non-employment to employment in the nineteen eighties. Four age cohorts are examined. The 30-32 cohort acts as a control.

In the pre-CFL years (1982-1984) the transition probabilities in the four age cohorts are fairly stable. The age class 16-20 has a distinct pattern, stabilizes after 1985 and shows a rapid decline beginning in 1988 which reflects decisions to attend high school in large numbers and is not of much interest to our analysis as workers in this class are mainly hired as apprentices. ${ }^{10}$ The cohorts $21-24$ and 25-29 show in the first year of the programme (1985) a positive increase in the probability of transition to employment which

\footnotetext{
${ }^{10}$ The increase in the ratio for the $16-20$ age class is a consequence of a drop in the active population (due to higher participation in schooling). The increase in the ratio for the age classes: $21-24,25-29$, and 30-34 is a consequence of an increase in the active population and a more than proportional hiring increase for these groups.

Workers in the age class 16-20 were hired mainly as apprentices. From 1986 to 1992, on average in Treviso and Vicenza 20,000 workers in this age class were hired yearly as apprentices but only 1200 on a basis of CFL (see Breda 1993, p. 165, Table 3 and VWH).
} 
is greater than that of the age group 30-32. This difference is reinforced in 1986 and 1987 but then declines in the following couple of years. During the period 1985-1987 there was an increase of $+39 \%$ in transitions for the 21-24 cohort, $+47 \%$ for the $25-29$ cohort, but only $+18 \%$ for the $16-20$ cohort and $+33 \%$ for the $30-32$ one).

Such evidence is at the root of the success claimed for the CFL programme, but it is very difficult to assess the extent to which it was in fact responsible for the increase in employment among those eligible to participate. A simple comparison between pre-programme and post-programme outcomes may be distorted by other parallel events, particularly by increasing participation in education which tends to delay the entrance age in the labour market - such that this in itself might in part be the cause of reduced unemployment levels, implying thereby that the effect of CFL might not be as great as would first appear. In order to control for such potential biases we set the evaluation problem in an econometric framework.

\section{The CFL evaluation strategy}

\subsection{The evaluation problem}

We want to assess the effect of the introduction of the CFL on the magnitude of youth employment, compared to what it would be if the new contract had not been implemented. Firms were not forced to participate in the programme and only "the good ones" 11 - firms with a credible training plan, and which had not fired substantial numbers of workers during the previous year - could apply. In order to evaluate the new programme much attention is paid below to constructing a suitable control group for comparison with the participating firms and to discussing the influence of omitted factors. The control group includes firms that were interested in hiring eligible employees but not interested in CFL; firms that applied to the CFL Commission and received approval but did not take up the programme for various reasons; and firms that applied and whose application was rejected. These three categories are not separately identifiable.

Many applications were rejected, mainly because the training plan presented by the applicant was not considered satisfactory. ${ }^{12}$ These firms are particularly good candidates for our control group as they presumably share many of

\footnotetext{
${ }^{11}$ The concern with spending money on "the bad and the ugly" was politically understandable as CFL was supported by the trade unions under a socialist government, so active policies from entrepreneurs was considered an essential counterpart to the expenditure of public money.

${ }^{12}$ According to several interviews with former members of the Regional Commission for Employment, almost half of the applications were rejected.
}

the characteristics of the participating firms. Both groups tried to engage in the programme, although, possibly, with different intensity.

Some firms were declared eligible but did not take up the offer of engagement in the programme for reasons unknown - possibly there was either a change in the firm's plans, or maybe it had a lack of workers with the required skills - which makes it difficult to devise an appropriate control. To our knowledge they are very few, particularly during the first years of the programme. The remaining firms were not interested in hiring eligible workers and were discarded. ${ }^{13}$

Firms $\left\{\begin{array}{l}\text { interested in CFL }\left\{\begin{array}{l}\text { applied sucessfully and took it up (participants) } \\ \text { applied sucessfully but did not take it up (control) } \\ \text { applied but were unsucessful (control) }\end{array}\right. \\ \text { non interested in CFL }\left\{\begin{array}{l}\text { interested in hiring young people (control) } \\ \text { non interested in hiring young people }\end{array}\right.\end{array}\right.$

To assess if the CFL programme improved labour market conditions for young people, an Intention to Treat framework (ITT) is necessary. The ITT measures the CFL impact on youth employment in general, while the Average Effect of Treatment on the Treated (ATT) measures the effect on youth employment in just those firms that took part in the programme. The ATT is useful for studying the reaction of those firms that took part in the programme to monetary incentives and flexibility in labour legislation. At the final stage, the ITT $s$ measured by multiplying the ATT value by the fraction of firms that took part in the programme.

The key question we want to answer is what is the effect of the programme treatment on the magnitude of youth employment, compared to what it would be if the treatment had not taken place. Let $Y_{1 i}$ and $Y_{0 i}$ be random variables representing the employment stock of eligible workers for cases of treatment and non-treatment respectively. The impact of participating in the programme for any firm $i$ is given by $\Delta_{i}=Y_{1 i}-Y_{0 i}$, a measure that is not directly observable as no firm can experience both treatment and non-treatment at the same time.

Let $D_{i}$ be a binary variable that takes the value 1 if a firm $i$ took up the programme and 0 if it did not. What is observed is:

$$
Y_{1}=D_{1} Y_{1 i}+\left(1-D_{i}\right) Y_{0 i}
$$

\footnotetext{
${ }^{13}$ The approach was suggested to us by Barbara Sianesi.
} 
The Average Treatment Effect on the Treated is the average gain due to the programme for firms that actually choose to participate: $E\left(Y_{1}-Y_{0} \mid D=1\right)=E\left(Y_{1} \mid D=1\right)-$ $E\left(Y_{0} \mid D=1\right)$.

The employment effect of firms in the control group is assumed equal to zero, in other words, firms that did not participate in the programme show no effects from its availability.

A large majority of firms had the option to participate in the programme, but some firms declined. Firms choosing not to participate may differ systematically from participants in respect of their levels of motivation and other important characteristics. The difference in motivation (or other characteristics) may itself lead to different results for the two groups, and thus bias the study estimates. For example, if the firms entering the programme are more prone to growth, or are bigger in size, thus allowing more people to be hired and to take part in the programme, any employment increase would be the result of selection and not of the programme.

\subsection{The matching assumptions}

A way out of this dilemma is to address the problem directly by making the two groups, treated and untreated firms, comparable on observed characteristics through a process of matching. A counterfactual analysis is constructed by identifying a "match" in the control group for each treated firm. The key assumption in the matching method is the conditional independence assumption (CIA) which states that programme outcomes are independent, and conditional on a vector of observable characteristics $X$

$$
\left(Y_{0}, Y_{1}|| D\right) \mid X
$$

However, when there are many conditioning variables it is extremely difficult to find a proper match. A more practical solution is to match on the propensity score, $p(X)$, which is defined as the conditional probability of participation given pre-participation characteristics:

$$
p(X)=\operatorname{pr}(D=1 \mid X) \text {. }
$$

Rosenbaum and Rubin (1983) demonstrated that if the CIA holds, matching on the propensity score results in an unbiased estimate of ATT.

Matching methods, by choosing and reweighing observations within the common support, eliminate biases arising from comparisons of the wrong units (comparing units outside the common support region), and biases arising from comparisons of the right units in the wrong proportions (differences in the densities of observable characteristics between treatment and comparison units), but not biases arising from unobservables. The CIA requiresxhat that, condi- tional to $X$, there be no unobserved heterogeneity left that affects the decision to join the programme. The CIA thus requires detailed knowledge of the factors that drive participation. In this paper the choice of a matching approach is motivated by the richness of the available information related to firms' heterogeneity and to job seekers' characteristics.

In general, after having run logit, probit or semiparametric estimations on pre-participation variables $X$, the fitted values, $p(X)$, are used in order to match participants with control units. Following Heckman et al. (1998) the form of the matching estimator can be set in the following framework

$A \hat{T} T=\sum_{i \in T} \omega(i)\left[Q_{1 i}-\sum_{j \in C} W(i, j) Q_{0 j}\right], \quad$ for $X \in \bar{X}$

where $Q_{1 i}$ is a function of the treatment $T$ outcome, $Y_{1 i} ; Q_{0 j}$ is a function of the comparison $C$ group outcome, $Y_{0 i} ; W(i, j)$ is a weight, with $\sum_{j \in C} W(i, j)=1$, which depends on $p$-score and on the kind of matching used (nearest-neighbours, kernel, ...); $\omega(i)$ is a weight that accounts for heteroscedasticity and scale; $\bar{X}$ is the common support on the treated and untreated units: $\bar{X}=X_{1} \cap X_{0}$.

$t^{0}$ is the date at which the participants entered the programme, $t^{1}$ is the earlier period and $t^{2}$ the period from $t^{0}$ onward. Exploiting the panel data information, the ATT estimate is obtained by the difference between matching estimates before and after treatment (Heckman et al. 1998). In terms of expression (5) the programme outcomes are defined as $Q_{1 i}=\left(Y_{1 i t^{2}}-Y_{1 i t^{1}}\right)$ and $Q_{0 j}=\left(Y_{0 j t^{2}}-Y_{0 j t}\right)$.

The identification assumption is the usual conditional independence assumption CIA, in differences:

$$
E\left(Y_{0 t^{2}}-Y_{0 t^{1}} \mid X, D=1\right)=E\left(Y_{0 t^{2}}-Y_{0 t^{1}} \mid X, D=0\right)
$$

in other words, no difference in the outcome trend between non participants and participants when there is no treatment. In a context of a linear model with an additively separable error term, $u_{0 t}$, this condition is

$E\left(u_{0 t^{2}}-u_{0 t^{1}} \mid p(X), D=1\right)=E\left(u_{0 t^{2}}-u_{0 t^{1}} \mid p(X), D=0\right)$

in other words, in absence of treatment, given appropriate controls, there is no difference in the residuals of the outcome trend between non-participants and participants.

The estimation strategy assumes that the programme does not affect the control group - a reasonable assumption because although engagement in the CFL programme in the eighties was widely diffused, a large number of young workers were available for hiring by untreated firms. 
Table 3 Treated firms and eligible worker cohorts

\begin{tabular}{|c|c|c|c|c|}
\hline \multirow{2}{*}{$\begin{array}{l}\text { Period of observatior } \\
\text { Pre-treatment }\end{array}$} & \multirow[b]{2}{*}{ Treatment } & \multirow[b]{2}{*}{ After-treatment } & \multicolumn{2}{|c|}{$\begin{array}{l}\text { Number of firms entering } \\
\text { the programme (participants) }\end{array}$} \\
\hline & & & $\begin{array}{l}\text { Workers } \\
\text { 1961-1964 } \\
\text { birth cohort* }\end{array}$ & $\begin{array}{l}\text { Workers } \\
\text { 1957-1960 } \\
\text { birth cohort }^{\circ}\end{array}$ \\
\hline 1985/1-1985/12 & 1986/01 & 1986/02-1986/12 & 153 & 49 \\
\hline 1985/2-1986/1 & $1986 / 02$ & 1986/02-1987/1 & 87 & 39 \\
\hline $1985 / 3-1986 / 2$ & $1986 / 03$ & $1986 / 03-1987 / 2$ & 77 & 26 \\
\hline $1985 / 4-1986 / 3$ & 1986/04 & $1986 / 04-1987 / 3$ & 77 & 27 \\
\hline $1985 / 5-1986 / 4$ & $1986 / 05$ & $1986 / 05-1987 / 4$ & 88 & 32 \\
\hline $1985 / 6-1986 / 5$ & 1986/06 & 1986/06-1987/5 & 74 & 23 \\
\hline 1985/7-1986/6 & 1986/07 & 1986/07-1987/6 & 100 & 33 \\
\hline 1985/8-1986/7 & 1986/08 & 1986/08-1987/7 & 30 & 11 \\
\hline 1985/9-1986/8 & 1986/09 & 1986/09-1987/8 & 98 & 37 \\
\hline 1985/10-1986/9 & $1986 / 10$ & 1986/10-1987/9 & 118 & 53 \\
\hline $1985 / 11-1986 / 10$ & $1986 / 11$ & $1986 / 11-1987 / 10$ & 109 & 47 \\
\hline 1985/12-1986/11 & $1986 / 12$ & 1986/12-1987/11 & 61 & 19 \\
\hline Total & & & 1072 & 396 \\
\hline
\end{tabular}

* Workers' age is 21-22 for birth cohort 1964, 22-23 for birth cohort 1963, . . 24-25 for birth cohort 1961. 'Workers' age is 25-26 for birth cohort 1960, 26-27 for birth cohort 1959, . . 28-29 for birth cohort 1957. A firm can be present in both groups Firms that hire only in a single age cohort cannot be used as a control for the other age cohort, so that any possible substitution effect is avoided.

Observable characteristics in the last pre-treatment month are used for selection for the $p$-score matching.

\section{Empirical findings}

\subsection{The employment impact}

The important questions are how much did youth employment increase in firms that participated in the programme, ATT, and how was this reflected in an increase in overall youth employment, ITT?. Eligible workers are those aged $21-29,{ }^{14}$ and the age range has been split into two classes, 21-24 and 25-29. ${ }^{15}$ Treated firms are firms that at the stated month in 1986 hired people under the CFL (Table 3). Untreated firms are defined as firms that did not enter the CFL programme in the same month; or they are non-participants or they are not-as-yet participants but might enter the programme at a later stage (see Sect. 3.1). ${ }^{16}$

\footnotetext{
${ }^{14}$ The age class 15-20 was excluded for two reasons. Firms can exploit the apprenticeship programme and this blurs the results; by excluding the age class 15-20 we get rid of any contamination between the two contracts. Secondly, the extension of school attendance drastically reduced the number of eligible workers in this class over time.

The panel excludes firms that are established or that failed during the study years, so the possible variation in stock due to this natural process is ruled out.

${ }^{15}$ This allows the separation of the programme's influence on the less skilled workers from its influence on the more skilled workers, likely to have a college or university education (see Sect. 2). On the association between the first entrance into the labour market and the termination of fulltime education over the long period in Treviso and Vicenza, see Canu and Tattara (2005) par. 3

${ }^{16}$ The probability of hiring a worker under CFL for firms hiring an eligible worker in 1986 is assumed to be independent from hiring a worker under $\mathrm{CFL}$ in the near future.
}

Workers are clustered according to birth date. The ATT is estimated through a DID-p.score-matching estimator and identifies the average effect of the programme as the difference between the average outcomes in the participating group and those in the control group. This is achieved by comparing the two groups in terms of the changes in the average monthly employment levels of eligible workers over 12 months before, and a similar period after, entering the programme, given the appropriate control variables. The entrance date slides through time, from 1.1986 to $12.1986^{17}$ and Table 3 presents the sliding observation window used in the estimate, with the number of firms taking up the programme. The observation window is centred in the entrance

A referee pointed out that, because of the identification scheme, a firm can be in the control group in one month and in the treated group in another month. As some observable characteristics that enter the p-score estimation are time invariant (within one year), the p-score might not change much from time to time and yet the same firm could be included in two different groups. Possibly there are unobserved variables that induce firms to switch from non participation and this weakens the matching procedure.

In practice the objection is not very relevant as such firms entering the control group account for less than $2 \%$ of the total non-treated firms. Of course the criticism makes clear that the set of control variables might not be totally adequate (it seldom is), but the test made on the matching procedure and reported in Fig. 2 shows that the assumptions necessary for the variation in difference estimation are satisfied. One needs also to take into account that the large majority of firms are of small size, that hiring-separations change considerably within one year and that an addition of one worker makes a lot of difference for small firms. The possibility that firms use CFL to select their personnel on the basis of parameters that are non-observables is a very serious concern and is directly taken up in Sect. 4.4.

${ }^{17} \mathrm{CFL}$ started in 1985 but only a few firms participated, so the programme is evaluated from 1986. 
Fig. 2 Number of 21-24 year-old workers by firm treatment status, after $P$-score-matching

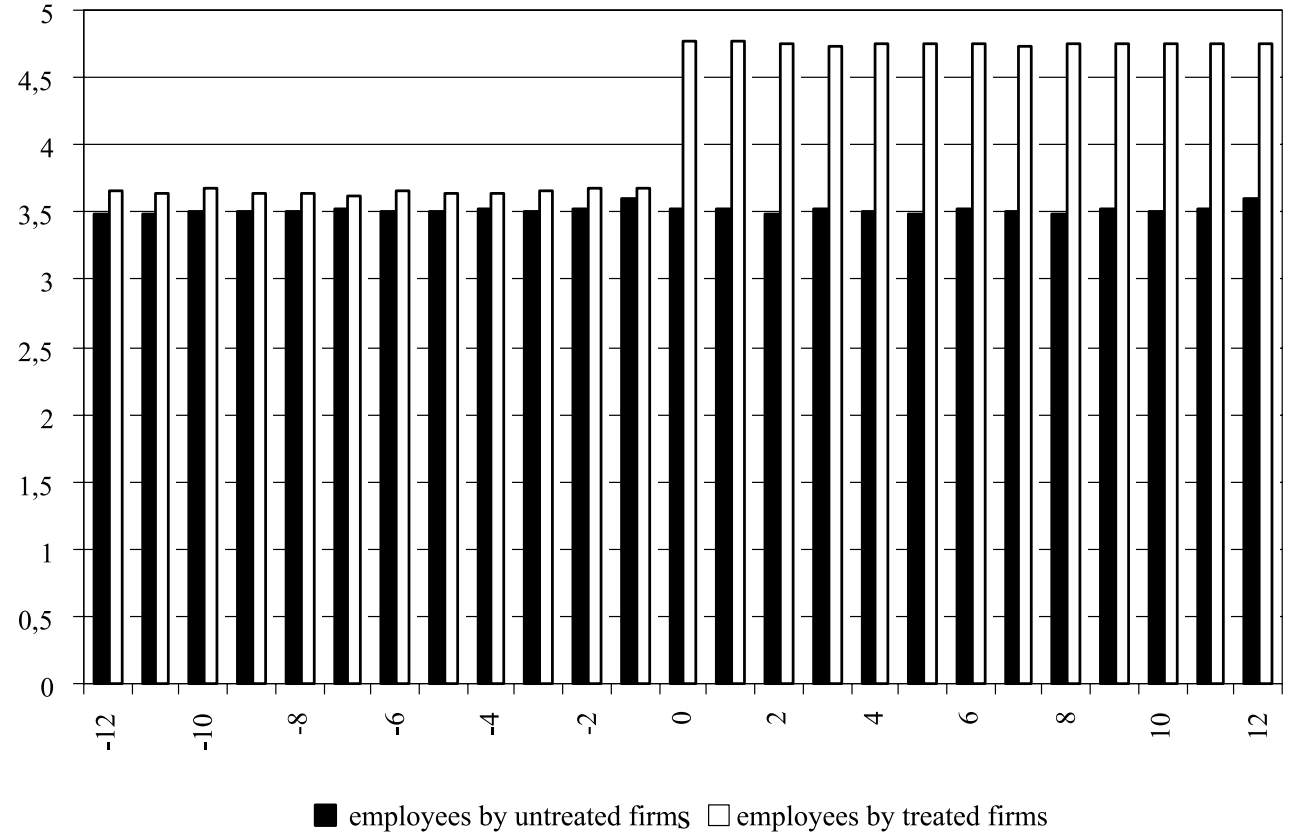

Table 4 Results of AR(1) model for the yearly variation of eligible workers

period of 12 months before and after entrance into the programme proves to be long enough so that the result is not blurred with extemporaneous spikes.

Firms choose to participate and this causes an important bias in our estimate. Treated firms' past employment records show that they employed many more young workers in the pre-treatment period than untreated firms. In addition, treated and untreated firms are remarkably different in size and employee composition as reported in Table 10 of the Appendix. Consequently, there is a need to construct a control by identifying a proper "match" in the control group for every treated firm. As indicated earlier, the employment effect of the programme is estimated through a two-stage procedure. First, the matching process sets up a treated and an untreated group similar in terms of their propensity scores (Table 10). Second, for each firm, the variation in employment stock over time is computed (the difference between pre-treatment and post-treatment). The ATT estimator (DID-p.score-matching estimator) is computed as the average difference between the matched treated and untreated firms.

Firms are pooled according to the month in which they joined the programme and a logit model for each of the 12 groups is estimated on the following pre-participation exogenous variables (measured one month before entering the programme): size, sector, industrial area dummies, firm age, number of males, blue-collars (proxy for capital or labour intensity), apprenticeships (proxy for the firm's inclination to use fixed-term contracts and training contracts), eligible workers and the yearly variation of eligible workers. In order

\begin{tabular}{ll}
\hline Lagged yearly variation of the eligible workers & 0.9591724 \\
(standard error) & $(0.0005126)$ \\
Adj R-squared & 0.9049
\end{tabular}

to capture non-linearity, interaction and second order terms are allowed (see Table 11 in the Appendix).

Yearly variations in the employment of eligible workers in the pre-treatment period are included among the variables in order to control for the firms' different rates of growth. The lagged employment variable is a good forecaster for future behaviour of participants as far as employment is concerned. The autoregressive estimate of the yearly variations in eligible workers in the most recent past is estimated by OLS over the period January 1982-December 1984: the coefficient of the lagged employment variable is significantly close to 0.95 with a high $R^{2}$ (Table 4).

We matched participant and non-participant firms with the closest $p$-scores and from the same month observation (symmetric difference in difference matching). The calliper nearest-neighbour matching with a tolerance under $1 \% \mathrm{im}$ poses a common support and excludes less than $5 \%$ of the participant population. ${ }^{18}$ Overall, matching on the estimated

\footnotetext{
${ }^{18}$ In some cases we imposed not only the nearest neighbour but the five nearest. By doing this the estimate improved but the variance increased. The tolerance and the number of comparisons were chosen in order to min-
} 
Table 5 Estimated average treatment effect on the treated (DIDp.score-matching)

\begin{tabular}{lll}
\hline Eligible age cohorts & $21-24$ & $25-29$ \\
\hline$A \hat{T} T$ & 1.101183 & $\begin{array}{l}0.9996684 \\
(\text { bootstrap standard error) }\end{array}$ \\
\hline
\end{tabular}

propensity score balances the $X$ 's in the matched samples extremely well. Seasonality, which is particularly relevant in the hiring of young people, is dealt with by matching treated and control firms month by month and comparing the 12 month pre-treatment period with the 12 month posttreatment period. Twelve $A \hat{T} T_{t}$ are computed, one for each month of treatment, but only the weighted (according to the observed number of treated firms in a given month) average of the $A \hat{T} T_{t}$ is reported:

$$
\begin{aligned}
A \hat{T} T=\sum_{t} A \hat{T} T_{t} \cdot P\left(D_{t} \mid D=1\right) \\
t: \text { January, } \ldots, \text { December } 1986 .
\end{aligned}
$$

Control group firms are the same across the repeated procedure (14.308 firms), but the specific observations used in the logit estimate vary for each group, depending on the specific entrance date.

Figure 2 shows the monthly employment stock of 21-24 year-old workers (dependent variable), both treated and untreated, measured with respect to the average firm's size (20 employees), centred in the month in which, for the first time, the firm hires a CFL worker. The horizontal axis measures the distance in months in relation to the month that the firm joined the programme, which is labelled 0 .

Table 5 reports the ATT estimates from Eq. (4), summarized according to Eq. (7). Over the treatment period, the number of eligible workers employed by treated firms differed significantly from the number of eligible workers employed by untreated firms, and the difference is close to 1 . The introduction of CFL, evaluated through the DID-p.score-matching, had a fairly strong effect in increasing employment of the eligible age cohort in the firms participating in the programme. On average, the treated firms each hired one extra young worker more than the untreated firms. The outcome is very similar for the two age cohorts. On average, participating firms increased their eligible employment stock by $5 \% .{ }^{19}$

imise outcome differences between the two groups during the pre-treatment period.

${ }^{19}$ If people hired under the programme were already employed, does a positive coefficient for the programme imply an increase in employment? The answer is affirmative. All other things being equal, workers who terminate their previous jobs (whether through quitting or being fired), are probably replaced by new workers, and so the situation for the firms that lose
Table 6 The number of firms that joined the programme, and the number of eligible firms: 1985, 1986, 1987

\begin{tabular}{lcccc}
\hline & $\begin{array}{c}\text { Year } \\
1985\end{array}$ & 1986 & 1987 & $\begin{array}{l}\text { 1986-1987 } \\
\text { average }\end{array}$ \\
\hline $\begin{array}{l}\text { New firms that joined } \\
\text { the programme }\end{array}$ & 1044 & 3912 & 5514 & 4713 \\
$\begin{array}{l}\text { Number of eligible firms } \\
\begin{array}{l}\text { Percentage of firms that } \\
\text { joined the programme }\end{array}\end{array}$ & 24612 & 22298 & 18675 & 20487 \\
\hline
\end{tabular}

Matching allows us to remove the main differences between participating and non-participating firms in the 12-month pre-participation period. Some heterogeneity, which is fairly constant over time (about 0.2 ), is still present (Fig. 2), and is dealt with successfully by DID.

Many studies report a decrease in the probability of employment before participation in a programme like CFL. This effect was first observed by Ashenfelter and is therefore referred to as Ashenfelter's dip. The most popular explanation for it is that firms that are planning to take part in the programme in the future anticipate their participation and therefore reduce their recruitment. Such a dip in employment would cause an over-estimate of the CFL impact ${ }^{20}$ but this possibility is ruled out by the stable pattern of employment shown in Fig. 2.

Admission to the programme was limited to firms whose training plans had been approved. In fact, several applications were rejected and about $50 \%$ of potentially eligible firms did not apply. ${ }^{21}$ To assess the programme's overall impact on youth employment, we must take into account the probability that a firm will participate in the programme, which is $1 / 4$, on average, for the years 1986-1987 (Table 6 last row). The impact effect of the CFL on youth net employment for participating enterprises is positive and statistically significant, although the overall general impact on youth employment is limited, since it is only a small fraction of the estimated ATT, in other words, $1.2 \%$.

\subsection{A sensitivity analysis}

The lagged yearly variation in employment of eligible workers plays an important role in identifying the programme's impact. A sensitivity analysis helps to understand whether

their workers remains the same. Sooner or later the system fills the vacancy caused by the CFL hiring with an unemployed worker.

${ }^{20}$ The "dip" typically occurs if firms are selected which experienced a decline in the number of their employees prior to engaging in the programme such that a subsequent increase in employment might be attributable to the "dip" and not to the programme.

${ }^{21}$ Breda (1993, p. 161ff.). 
Table 7 Estimated average treatment on the treated according to pre-treatament growth rates in employment (DID-p.score-matching)

\begin{tabular}{lllllll}
\hline $\begin{array}{l}\text { Employment growth } \\
\text { Eligible age cohorts }\end{array}$ & $\begin{array}{l}\leq-1 \\
21-24\end{array}$ & $25-29$ & $\begin{array}{l}=0 \\
21-24\end{array}$ & $25-29$ & $\begin{array}{l}\geq 1 \\
21-24\end{array}$ & $25-29$ \\
\hline $\begin{array}{l}A \hat{T} T \\
\text { (bootstrap std. err.) }\end{array}$ & $\begin{array}{l}1.250839 \\
(0.065365)\end{array}$ & $\begin{array}{l}1.077297 \\
(0.069879)\end{array}$ & $\begin{array}{l}0.9748806 \\
(0.013941)\end{array}$ & $\begin{array}{l}0.9732956 \\
(0.017048)\end{array}$ & $\begin{array}{l}1.28522 \\
(0.048300)\end{array}$ & $\begin{array}{l}0.9856224 \\
(0.076903)\end{array}$ \\
\hline
\end{tabular}

Table 8 Estimated average treatment effect on the treated computed with respect to the age classes $15-20 ; 30-32 ; 35-40$ (DID-p.score-matching)

\begin{tabular}{llllll}
\hline Eligible age class: 21-24 & & \multicolumn{2}{l}{ Eligible age class: 25-29 } \\
\hline $\begin{array}{l}A \hat{T} T \text { 15-20cohort } \\
\text { (bootstrap std. err.) }\end{array}$ & $\begin{array}{l}0.1576029 \\
(0.0226783)\end{array}$ & $\begin{array}{l}A \hat{T} T_{30-32 \text { cohort }} \\
\text { (bootstrap std. err.) }\end{array}$ & $\begin{array}{l}-0.0031796 \\
(0.0158533)\end{array}$ & $\begin{array}{l}A \hat{T} T \text { 35-40cohort } \\
\text { (bootstrap std. err.) }\end{array}$ & $\begin{array}{l}0.0022628 \\
(0.0133871)\end{array}$ \\
\hline
\end{tabular}

firms with different growth rates performed differently in respect to this variable. A simple sensitivity analysis looks at the estimated effects on employment in relation to various rates of growth in employment experienced by the treated.

Participating firms are grouped into firms with decreasing, constant and growing employment one month prior to treatment ${ }^{22}(-1,0,+1)$, and for each set the matching procedure is replicated. It is found that the employment gains are virtually the same across the subsamples (Table 7). After joining the programme, firms with decreasing employment increased their stock of eligible workers by an average of one additional worker over the pre-treatment stock; the same is true for the firms that previously had constant employment; and also for those that had increased their stock of employees before joining the programme.

\subsection{Income and substitution effect}

Did the increase in employment of eligible workers lead to the displacement of other workers so that the overall result was less satisfactory than assumed? The employment increase in the age cohort 21-29 might be at the cost of a parallel employment decline in younger or older workers. An assessment of whether the programme did have such an impact needs to proceed net of the so-called "bookkeeping" effects. These refer to the fact that a reduction in the cost of a group of workers has two standard effects: a "substitution" effect, and an "income" effect - whereby firms may save money and so effectively "increase their income" which could be spent on hiring more workers - both eligible and

\footnotetext{
${ }^{22}$ Most of the participating firms had a growth rate equal to zero, which is also the median. The extension of coverage to more months previous to treatment altered the relative number of firms belonging to the three groups but did not alter the estimate results.
}

non-eligible. For example, the fact that eligible firms might have hired non-eligible workers at the upper margin of the CFL age class, might simply reflect a strong "income" effect rather than the absence of a substitution effect (which would have resulted in a decline in older workers).

In order to check for an "income" effect we extended the analysis to workers in the age group 35-40. They are less prone to the substitution effect (of being replaced by younger eligible workers), but might have been influenced by an "income" effect (and hired because an enterprise had more money available). Mature workers have different experiences and skills compared with those participating in the CFL programme, who are mainly new entrants, and are liable to play a very different role in a firm's organization. A substitution of workers in the 35-40 age group by eligible (younger) workers participating in CFL is probably very limited, while a positive "income" effect for the firm will be reflected in a general increase in hiring in all age classes.

In order to test the magnitude of the "substitution" and "income" effects we computed the Average Treatment Effect on the Treated in respect of employment variations for the age classes: $15-20,30-32$, and 35-40 experienced by participing and non-participating firms (with participating firms being defined as those employing CFL workers from the eligible age classes: $21-24 ; 25-29$ ). (Table 8). ${ }^{23}$

The relative difference in employment for the age class $35-40$ between treated and control groups is insignificant and confirms the absence of a positive "income" effect for participating firms (Table 8). There is, however, a positive, but minimal, CFL effect on the employment of workers aged $15-20^{24}$ because some younger workers were substituted for

\footnotetext{
${ }^{23}$ We have limited ourselves to 40 years of age because older workers would introduce much heterogeneity in the sample.

${ }^{24}$ See previous note 11 on the limited number of workers hired under $\mathrm{CFl}$ contract in this age class.
} 
those in the next, higher, age class (measured by one more employee for every five firms of average size, in other words, approximately one in 100 workers, but the CFL net effect on the 21-24 year old workers is five times as big. ${ }^{25}$ For the age class 30-32, the relative difference in employment between treated and control groups is insignificant and demonstrates that for this group there was an absence of any substitution effect (Table 8).

\subsection{Selection bias}

Matching estimators mimic a randomized experiment expost by constructing a comparison group as similar as possible to the treatment group. Even with the most informative data, matching can only control for observable differences between the treatment and comparison groups, and the method assumes that there is no remaining unobserved heterogeneity between the two groups that could possibly bias the treatment effect estimate (Kluve and Schmidt 2002, p. 427). Eligible workers were not only hired by participants through a CFL contract, but also by participants through an open-ended contract, and also by non-participants. Why would any firm hire an eligible worker without using CFL? Possibly different firms hire different kinds of young people and this can make control firms different in their hiring policies.

Different propensities to hire eligible workers on CFL contracts suggest the possibility of unobserved heterogeneity between the two groups. The obvious explanation for varying propensities to employ eligible workers on CFL contracts is that in order to employ better young people - in other words, high-quality employees who want a long-term relationship with the firm - an open-ended contract is required. Some firms may have targeted "the cream of the crop"; other firms maybe went for "bulk purchase and discount". ${ }^{26}$ If this is true, our control group would prove inappropriate. Firms with growing employment needs chose to participate while firms more prone to high quality growth, and requiring a limited number of workers, went into the control group, and the positive outcome for the participants is the result of selection.

In fact, participants hired a substantial number of eligible young workers on open-ended contracts in the same month that they hired CFL workers. Among all workers hired by participants, $49 \%$ were CFL employees and the rest were hired on open-ended contracts, a clear sign that many partic-

\footnotetext{
${ }^{25}$ We speculate that firms looking for young people look for people around 18-24 years of age, but within this group they prefer to hire workers after service in the army (which occurs at 19-20 years of age) because wth CFL it can be done at the same cost as when hiring apprentices.

${ }^{26}$ The segmentation of the labour market due to the diffusion of fixed-term contracts in recent years, is considered, for example, by Boeri (1999), Blanchard and Landier (2002) and Cipollone and Guelfi (2006).
}

ipants choose to use the two contracts in parallel, with selection in mind. Adding a new worker to the CFL project would not have proved particularly expensive, but entrepreneurs had other reasons to choose high quality workers. Firms use the new CFL contract in parallel with the open-ended contract, with its higher wages, for selection purposes, but this behaviour seems not to affect crucially the composition of our control group. Both types of firms, treated and untreated, hired eligible workers on open-ended contracts; both were sensitive to the labour supply portion that could be attracted by offering better employment conditions; and both hired a mix of ordinary and high quality workers. ${ }^{27}$

\section{The CFL reforms}

The CFL reforms, in June 1988 and January 1991, reduced the financial rebate for participating non-artisan firms by $50 \%$, twice, leaving the benefit intact for artisans (Table 1). The benefits related to contract flexibility were basically untouched. Very few firms joined the programme after the reform and the CFL was mainly used by artisan firms, and had a limited effect on total employment.

The effect of the reforms on the firms that chose to join is now the most interesting question. Given that, when launched, the programme had many adherents and that the programme significantly altered firms' behaviour, ${ }^{28}$ one would expect that those firms that lost the financial benefits (non-artisan firms) would return to their starting situation. Surprisingly, non-artisan firms that originally took up the programme carried on with the same employment as before.

The ATT estimates the average employment variation due to the programme reforms on firms with ongoing CFL participation. Treated and control groups are non-artisan and artisan firms. The parameter estimate is an ATT conditional to those firms who joined the CFL programme at baseline.

Treated and control firms are exogenously identified (they belong to the non-artisan or artisan set), and the basic problem is heterogeneity between the treated and the control groups, in other words, a problem of diversity, not a problem of selection such as the one we encountered in the previous section.

Observable heterogeneity is controlled by the matching procedure. Artisan and non-artisan firms differ primarily in size and sector, and matching 'loses' about half of treated firms. Even after matching and balancing the observable

\footnotetext{
${ }^{27}$ Firms in the control group include a substantial number of firms whose application was rejected, and their demand for labour was presumably very similar to the demand for labour expressed by the treated firms.

${ }^{28}$ Empirical observations show that the benefit reduction was accompanied by a drastic fall in the number of non-artisan firms joining the programme.
} 
Fig. 3 Residuals of the Regression $Y_{1 i}=X_{i} \beta_{0}+u_{i}$ and confidence interval constructed around the residuals of the regression $Y_{0 j}=X_{j} \beta_{0}+u_{j}$

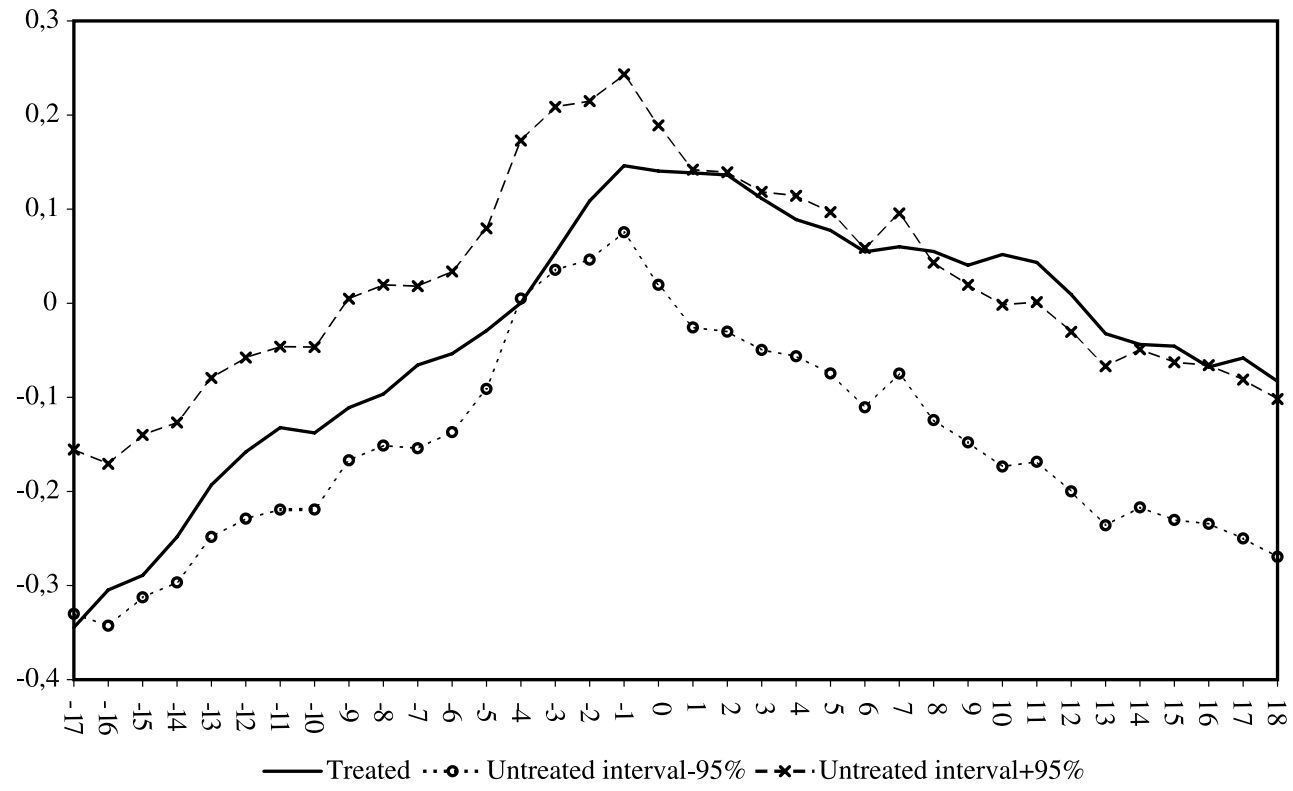

Table 9 Estimated average treatment effect on the treated in relation to the two CFL reforms (DID- $p$.scorematching)

\begin{tabular}{lllll}
\hline $\begin{array}{l}\text { Reform period examined } \\
\text { Eligible age cohort }\end{array}$ & \multicolumn{2}{l}{ from 6.1988 to 5.1989 } & \multicolumn{2}{l}{ from 1.1991 to 12.1991 } \\
& $21-24$ & $25-29$ & $21-24$ & $25-29$ \\
\hline $\begin{array}{l}A \hat{T} T \\
\text { (bootstrap standard error) }\end{array}$ & $\begin{array}{l}0.107756 \\
(0.017400)\end{array}$ & $\begin{array}{l}\text { (0.020937 } \\
(0.029064)\end{array}$ & $\begin{array}{l}0.043564 \\
(0.010108)\end{array}$ & $\begin{array}{l}0.025117 \\
(0.013646)\end{array}$ \\
\hline
\end{tabular}

variables - the stock of eligible workers for artisan and nonartisan firms - in the period before the reforms artisan and non-artisan firms exhibit different patterns through time. This heterogeneity ${ }^{29}$ can be addressed by using regressionadjusted matching. ${ }^{30}$ Heckman et al. (1998) combine the matching method and regression adjustment on the $X$. Their method extends beyond the classical matching process by utilizing information about the functional form of the outcome equation and by directly confronting the problem of the difference in behaviour over the pre-treatment period.

Regression-adjusted matching is performed through the following procedure (Heckman et al. 1998). Assume a conventional econometric model for outcomes in the untreated state that is additively separable in the observable $X$ and unobservable characteristics $U$ :

$$
E\left(Y_{0} \mid X, D=0\right)=X \beta_{0}+E\left(U_{0} \mid X, D=0\right) .
$$

\footnotetext{
${ }^{29}$ Blundell et al. (2004) observe that "for the evaluation to make sense with heterogeneous effects, we must guarantee that the distribution of the relevant observable characteristics is the same in the four cells defined by eligibility and time". They suggest using two propensity scores: one for eligibility and one for the time period.

${ }^{30}$ We do not use this technique in the previous analysis because the lagged employment variation of the eligible workers accounted for any selfselection. Thus, after matching there was no a-priori reason to expect a different response to the cycle from treated and untreated firms (Table 5 and Fig. 2).
}

Before estimating ATT by matching methods (5), $X \hat{\beta}_{0}$ is removed from $Y_{0}$ and $Y_{1}$ by setting $Q_{1 j}=\left(Y_{1 i}-X_{i} \hat{\beta}_{0}\right)$ and $Q_{0 j}=\left(Y_{0 j}-X_{j} \hat{\beta}_{0}\right)$.

In order to account for the different reactions to the business cycle by the treated and the untreated firms, the amount of non-CFL recruitment is considered. Indeed, treated (nonartisan) firms and control (artisan) firms have a different cyclical behaviour through time - previous controls given - and a focus on non-CFL recruitments for the two categories of firms captures a picture of the variability that derives from the cycle effect. ${ }^{31}$ Figure 3 plots the residuals of the regression of the employment variable for the treated for the age class 21-24 after regression-adjusted matching, once observable factors have been properly controlled for. The horizontal axis measures the elapsed time, in months, in relation to the beginning of the first reform in 1988, which is labelled 0 .

Firms that were faced with a much reduced financial benefit, did significantly cut the number of their new CFL contracts, ${ }^{32}$ but youth employment in the eligible age classes did not decline (Table 9).

\footnotetext{
${ }^{31}$ Observables are quite balanced between treated and untreated firms. Results are available on request.

${ }^{32}$ In a couple of years new CFL in Treviso and Vicenza almost halved, Breda (1993, p. 167). If artisan firms did not change their attitude, CFL by non artisan firms were reduced to very small numbers, indeed.
} 
One possible explanation for this lies in the rigidity of labour demand by the firms. Once a firm joined the programme, its structure adapted to the new situation (in terms of production volumes, market positioning, and other aspects). The enterprise was faced with a choice between retaining the CFL worker as soon as the contract came to maturity (50\% on average were retained $\left.{ }^{33}\right)$, or shifting to a new worker, but it was unwilling to decrease the employment level, all other things being equal, despite the fact that the financial benefit had been reduced. So treated and control firms do not behave differently as far as the ongoing employment level of the eligible workers is concerned, although new CFL recruitment was only undertaken by artisan firms. ${ }^{34}$

\section{Conclusions}

The CFL programme was introduced in Italy in 1985 , to relieve youth unemployment. The programme provided firms with a substantial reduction in social security contributions and a wage reduction; it was virtually the only fixed-term contract available for employers, having a maximum duration of two years; it allowed firms to hire directly without having to go through a government agency. This paper has argued that CFL was conducive to net job creation by firms that took it up because employers that took part in the programme strongly reacted to the fiscal benefits, the opportunities for direct hiring and the determinate duration of the contracts.

Our results complement the study by Contini et al. (2002), which measured the impact of the programme on youth employment at the national level through the analysis of temporal and territorial variations in relative labour costs for eligible employers, but found no evidence of a policy impact (Contini et al. 2002). Our richer dataset allows us to evaluate the programme's consequence for the number of young people hired by the participating firms and so produce a more informative estimate. Firms reacted promptly to the programme, and the average treatment effect on the treated is statistically significant and positive. The indirect effect of the programme on workers outside the targeted group has been scrutinized and no sizeable substitution effect has emerged, leading us to conclude that the impact of the intervention on the targeted group produced a positive net effect for the economy. In contrast to Contini et al. (2002) our study provides new evidence supporting active labour market interventions, also in the

\footnotetext{
${ }^{33}$ Breda (1993, p. 167).

${ }^{34}$ The result is only in part due to the fact that about $50 \%$ of CFL contracts were transformed into open-ended contracts: the employee stock of untreated firms is stable independent of such transformations.
}

face of many sceptical findings for other European countries (Kluve and Schmidt 2002; Contini and Revelli 2004).

The size of the overall effect in Treviso and Vicenza provinces was lessened by the programme's limited diffusion, and this had at least two causes. First, in a very rigid labour market, where terms and conditions of employment were negotiated in detail at the national level, firms took advantage of the new contract form - to separate the wheat from the chaff. Better educated workers or, generally speaking, workers with higher productivity, were offered open-ended contracts and higher entrance wages, while low productivity workers were hired through CFL, on fixed-term contracts and lower wages. Thus, CFL aided the process of screening workers for their job suitability. The occurrence of the programme intervention in a very rigid situation fostered competition among workers, and among firms, and improved the economy's employment performance. This argument is one of the main policy directions identified by the Manpower and Social Affairs Committee of the OECD (Kluve and Schmidt 2002, p. 421). Second, the programme was burdened by a series of restrictions aimed at selecting "good" employers. Employers were selected on the basis of an employment history free of recent substantial firings in order to avoid subsidizing firms which might have reduced employment prior to engaging in the programme with the intention of re-hiring previously employed youths on a temporary employment basis. Also, many applications were rejected on the grounds that the proposed training programmes they offered were poor.

The main lesson we can derive from the Italian experience is that the CFL programme had net, but limited, positive results on youth employment. To be an effective programme entry contracts must be framed in a sufficiently general and flexible framework, be able to take account of various forms of labour heterogeneity and skills, and, in order to reach a wide audience, must be relatively simple and not burdened by excessive bureaucratic impediments.

\section{Executive summary}

The On the Job Training Programme (Contratto di Formazione e Lavoro, briefly CFL) was a fixed-term contract introduced on Italy at the end of 1984 in order to facilitate the engagement of young workers in the labour market. The CFL was a scheme designed to integrate more young people into employment in a period of large unemployment.

The CFL contract was typical of what was happening in many European countries after the mid seventies when there was an increase in policies aiming to promote youth employment through active labour market policies. The schemes have varied somewhat in form and content over the years and 
for different countries, but generally have made recourse to two basic mechanisms 1) increase the skill levels of young workers through training 2) lower labour costs and increasing flexibility for targeted groups of workers, particularly in countries with rigid labour markets. High payroll taxes and over protective labour legislation are frequently asserted to be two of the main causes of the high rates of unemployment experienced in Europe in recent decades.

On the whole, the impact of programmes targeted at young workers in Europe has been mixed. Training programmes in particular have had poor results.

The Italian labour market, in the eighties, was a good example of a rigid labour market: there was a strong protection regulation (Statuto dei lavoratori) and a rigid system of wage determination, where a minimum wage, collectively agreed, was applied to all workers, with an almost total coverage. The CFL contract had two major advantages: it exempted employers from the payment of payroll taxes, and it was virtually the only form of fixed-term contract available for use. The contract provided a partial reform of existing employment protection legislation, introducing an automatic termination after a maximum of two years, and a wage subsidy (as well as reduced taxes) that might ease the distortions caused by the minimum wage legislation.

By considering the introduction of the CFL programme as an exogenous innovation, this paper evaluates its employment impact on a subgroup of young workers in two provinces in the North Eastern part of Italy. The experiences there are politically relevant as they show that the programme was conducive to net job creation (after taking into account possible substitution and displacement effects of other workers). Firms participating in the programme increased significantly their employment of young workers more than did non-participants, although the overall impact in the provinces was small, because only a limited number of firms that entered the programme.

The lesson that can be learned from the Italian experiment is that a training programme to be effective in relieving youth unemployment must be framed in a sufficiently general and flexible framework, be able to take account of various forms of labour heterogeneity and skills, and, in order to reach a wide audience, must be relatively simple and not burdened by excessive bureaucratic impediments.

\section{Kurzfassung}

Das Betriebsausbildungsprogramm (Contratto di Formazione e Lavoro, abgekürzt $C F L$ ) bestand aus einem befristeten Arbeitsvertrag, der Ende 1984 in Italien eingeführt wurde, um die Beteiligung junger Arbeiter am italienischen Arbeitsmarkt zu fördern. In einer von großer Arbeitslosigkeit gekennzeichneten Zeit sollte das CFL-Schema dazu dienen, mehr junge Leute in den Arbeitsmarkt zu integrieren.

Der CFL-Vertrag war ein typisches Beispiel für Entwicklungen, die in vielen europäischen Ländern nach Mitte der Siebziger im Gange waren. Zu dieser Zeit gab es einen Zuwachs an Programmen, die die Beschäftigung junger Menschen durch eine aktive arbeitsmarktbezogene Politik fördern sollten. In Form und Inhalt variierten die verwendeten Schemata mit der Zeit und in verschieden Ländern etwas, griffen aber im Allgemeinen auf zwei Hauptmechanismen zurück: 1) die Fähigkeiten junger Arbeiter durch eine Ausbildung zu verbessern 2) die Personalkosten zu senken und die Flexibilität für bestimmte Zielgruppen unter den Arbeitern zu steigern, vor allem in Ländern mit einer starren Struktur des Arbeitsmarkts. Es wird oft behauptet, hohe Lohnsteuern und protektionistische Arbeitsgesetzgebungen seien die zwei Hauptgründe für die hohen Arbeitslosenquoten in Europa in den vergangenen Jahrzehnten.

Im Großen und Ganzen hatten die Programme für junge Arbeiter in Europa eine gemischte Wirkung. Vor allem die Ausbildungsprogramme zeitigten kaum Ergebnisse.

Der italienische Arbeitsmarkt in den Achtziger Jahren war ein gutes Beispiel für die starre Struktur des Arbeitsmarktes: es gab eine streng protektionistische Gesetzgebung (Statuto dei lavoratori) und ein starres System vorgeschriebener Gehälter in dem ein Mindestlohn, der gemeinsam beschlossen wurde, ausnahmslos auf fast alle Arbeiter angewendet wurde. Der CFL-Vertrag hatte zwei große Vorteile: Er befreite die Arbeitgeber von Lohnsteuerzahlungen und war praktisch die einzige Art befristeter Vertrag, der zur Verfügung stand. Der Vertrag beinhaltete eine teilweise Reform der bestehenden Gesetzgebung zum Schutze der Arbeiter und führte eine automatische Beendigung des Arbeitsverhältnisses nach maximal zwei Jahren ein und einen Lohnkostenzuschuss (sowie eine Reduzierung der Steuern), der das durch die Mindestlohngesetzgebung entstandene Ungleichgewicht wieder wettmachen sollte.

Diese Abhandlung betrachtet die Einführung des CFLProgramms als eine exogene Innovation und beurteilt seine Auswirkung auf das Beschäftigungsverhältnis anhand der Untersuchung von zwei Untergruppen junger Arbeiter in zwei Provinzen im nordöstlichen Teil Italiens. Die dort gemachten Erfahrungen sind politisch relevant, denn sie zeigen, dass das Programm die Schaffung von Arbeitsplätzen förderte, Ersatz möglich machte und Firmen, die an diesem Programm teilnahmen, stellten mehr junge Arbeiter ein als Firmen, die nicht daran teilnahmen, obwohl die gesamte Wirkung des Programms in den Provinzen nur gering war, da nur eine begrenzte Anzahl an Firmen teilnahm.

Die Lektion, die man aus diesem italienischen Experiment lernen kann, ist, dass ein Ausbildungsprogramm 
zur Bekämpfung der Arbeitslosigkeit unter Jugendlichen in einem ausreichend allgemein gültigen und flexiblen Rahmen stattfinden, die Verschiedenartigkeit der Arbeit und unterschiedlichen Fähigkeiten der Arbeiter berücksichtigen und, um ein möglichst breites Publikum zu erreichen, relativ einfach gestaltet sein muss und nicht zu viele bürokratische Hürden zu überwinden sein sollten.

\section{Appendix A}

Table 10 presents statistics used in the matching procedure, comparing the treated and untreated firms on a number of variables before and after matching for 21-24 year-old workers. Matching makes the observable characteristics of treated and untreated firms very close.
Table 10 Selected variables before and after matching in 1986 for 21-24 year-old workers (standard errors in parentheses)

\begin{tabular}{|c|c|c|c|c|}
\hline \multirow[t]{2}{*}{ Variable } & \multicolumn{2}{|c|}{ Before matching } & \multicolumn{2}{|c|}{ After matching } \\
\hline & Untreated & Treated & Untreated & Treated \\
\hline Artisan & $\begin{array}{r}0.486674 \\
(0.499824)\end{array}$ & $\begin{array}{r}0.309595 \\
(0.462555)\end{array}$ & $\begin{array}{r}0.319580 \\
(0.466542)\end{array}$ & $\begin{array}{r}0.322266 \\
(0.467572)\end{array}$ \\
\hline Size & $\begin{array}{r}9.402192 \\
(28.54818)\end{array}$ & $\begin{array}{r}40.77052 \\
(191.3818)\end{array}$ & $\begin{array}{r}20.31966 \\
(36.94924)\end{array}$ & $\begin{array}{r}21.61426 \\
(43.51913)\end{array}$ \\
\hline Firm's age & $\begin{array}{r}7.939438 \\
(7.523244)\end{array}$ & $\begin{array}{r}3.240337 \\
(3.298095)\end{array}$ & $\begin{array}{r}7.356364 \\
(3.291211)\end{array}$ & $\begin{array}{r}7.347656 \\
(3.294926)\end{array}$ \\
\hline Number of males & $\begin{array}{r}5.768556 \\
(26.83482)\end{array}$ & $\begin{array}{r}20.05857 \\
(136.6268)\end{array}$ & $\begin{array}{r}13.57259 \\
(29.23727)\end{array}$ & $\begin{array}{r}13.89453 \\
(30.03775)\end{array}$ \\
\hline Number of blue collar workers & $\begin{array}{r}7.505811 \\
(28.44313)\end{array}$ & $\begin{array}{r}22.18906 \\
(121.1931)\end{array}$ & $\begin{array}{r}16.27197 \\
(30.34577)\end{array}$ & $\begin{array}{r}16.85449 \\
(35.37205)\end{array}$ \\
\hline Number of apprentices & $\begin{array}{r}0.934651 \\
(1.529179)\end{array}$ & $\begin{array}{r}1.750039 \\
(3.037047)\end{array}$ & $\begin{array}{r}1.355062 \\
(2.407525)\end{array}$ & $\begin{array}{r}1.34082 \\
(2.261941)\end{array}$ \\
\hline $\begin{array}{l}\text { Number of workers under } \\
20 \text { years old }\end{array}$ & $\begin{array}{r}1.437891 \\
(3.192878)\end{array}$ & $\begin{array}{r}2.481867 \\
(5.535429)\end{array}$ & $\begin{array}{r}2.376709 \\
(3.554734)\end{array}$ & $\begin{array}{r}2.453125 \\
(3.455307)\end{array}$ \\
\hline $\begin{array}{l}\text { Number of workers between } \\
21 \text { and } 24 \text { years old }\end{array}$ & $\begin{array}{r}1.649114 \\
(6.086053)\end{array}$ & $\begin{array}{r}3.303712 \\
(10.47834)\end{array}$ & $\begin{array}{r}3.458745 \\
(5.189902)\end{array}$ & $\begin{array}{r}3.662109 \\
(4.863844)\end{array}$ \\
\hline $\begin{array}{l}\text { Number of workers between } \\
25 \text { and } 29 \text { years old }\end{array}$ & $\begin{array}{r}1.621119 \\
(6.869436)\end{array}$ & $\begin{array}{r}4.527697 \\
(30.31506)\end{array}$ & $\begin{array}{r}3.666585 \\
(6.653488)\end{array}$ & $\begin{array}{r}3.891602 \\
(7.507505)\end{array}$ \\
\hline $\begin{array}{l}\text { Number of workers between } \\
30 \text { and } 32 \text { years old }\end{array}$ & $\begin{array}{r}0.768825 \\
(3.503462)\end{array}$ & $\begin{array}{r}3.284795 \\
(18.13499)\end{array}$ & $\begin{array}{l}1.730469 \\
(3.90936)\end{array}$ & $\begin{array}{r}1.900391 \\
(4.673697)\end{array}$ \\
\hline $\begin{array}{l}\text { Number of workers between } \\
33 \text { and } 35 \text { years old }\end{array}$ & $\begin{array}{r}0.645664 \\
(3.163205)\end{array}$ & $\begin{array}{l}3.616331 \\
(19.0575)\end{array}$ & $\begin{array}{r}1.47583 \\
(3.606509)\end{array}$ & $\begin{array}{r}1.523438 \\
(4.436523)\end{array}$ \\
\hline Lag eligible stock variation & $\begin{array}{r}-0.01924 \\
(1.355094)\end{array}$ & $\begin{array}{r}1.049493 \\
(2.652389)\end{array}$ & $\begin{array}{r}0.065104 \\
(2,005692)\end{array}$ & $\begin{array}{r}0.081055 \\
(1.330987)\end{array}$ \\
\hline
\end{tabular}


Before matching some variables are highly significant and these are the most important variables for selection into the program. When running the same estimation after matching no variable is significant, and this is clear evidence that the balancing procedure worked very efficiently (Table 11).

Table 11 Coefficients of the logit estimation ( $p$-values in parentheses)

\begin{tabular}{lrr}
\hline Variables & Before-matching & After-matching \\
\hline Artisan firm & -1.1502 & -0.16381 \\
& $(0.000)$ & $(0.688)$ \\
Size & 0.023211 & 0.07114 \\
& $(0.042)$ & $(0.102)$ \\
Firm's age & -0.08273 & 0.05029 \\
& $(0.551)$ & $(0.812)$ \\
Number of males & -0.0079 & -0.00805 \\
& $(0.187)$ & $(0.513)$ \\
Number of blue collar workers & -0.01327 & -0.04522 \\
& $(0.073)$ & $(0.055)$ \\
Number of apprentices & 0.072632 & 0.03765 \\
& $(0.196)$ & $(0.716)$ \\
Number of workers under & 0.014904 & -0.01115 \\
20 years old & $(0.565)$ & $(0.854)$ \\
Number of workers between & 0.027207 & -0.0238 \\
21 and 24 years old & $(0.246)$ & $(0.66)$ \\
Number of workers between & -0.00094 & -0.01043 \\
25 and 29 years old & $(0.967)$ & $(0.791)$ \\
Number of workers between & 0.0095 & 0.01247 \\
30 and 32 years old & $(0.828)$ & $(0.848)$ \\
Number of workers between & 0.035217 & -0.06893 \\
33 and 35 years old & $(0.429)$ & $(0.430)$ \\
Lag eligible stock variation & 0.112311 & 0.03138 \\
Territorial dummies & $(0.022)$ & $(0.721)$ \\
Sector dummies & Yes & Yes \\
\hline & & Yes \\
\hline
\end{tabular}

\section{References}

Blanchard, O.: European unemployment: the evolution of facts and ideas. Econ. Policy 45, 5-47 (2006)

Blanchard, O., Landier, A.: The perverse effects of partial labour market reform: fixed-term contracts in France. Econ. J. 112(480), 214-244 (2002)

Blundell, R., Costas Dias, M., Meghir, C., Van Reenen, J.: Evaluating the employment impact of a mandatory job search program. J. Eur. Econ. Assoc. 2(4), 560-606 (2004)
Boeri, T.: Enforcement of employment security regulations, on-thejob search and unemployment duration. Europ. Econ. Rev. 43(1), 65-89 (1999)

Breda, P.A.: I contratti di formazione lavoro e l'apprendistato. In: Ministero del lavoro, Regione Veneto (ed.) Il mercato del lavoro nel Veneto. Rapporto 1993. F. Angeli, Milano (1993)

Canu, R., Tattara, G.: Quando le farfalle mettono le ali. Riflessioni sull'ingresso delle donne nel lavoro dipendente. Econ. Lav. 2, 67-90 (2005)

Cipollone, P., Guelfi, A.: Financial support to permanent jobs. The Italian case. Politica Economica 22(1), 51-76 (2006)

Contini, B.: Introduction to the workshop: Lowering payroll taxes: does it help to improve employment opportunities? Turin 25-26 Feb 2000. http://www.labor-torino.it/pdf_doc/lpt.pdf (2000). Accessed 25 Jun 2009

Contini, B., Revelli, F.: On the welfare effect of a wage subsidy on youth labor: Italy's CFL program. WP September. http://www. laboratoriorevelli.it/_pdf/wp36.pdf (2004). Accessed 25 Jun 2009

Contini, B., Cornaglia, F., Malpede, C., Rettore, E.: Measuring the impact of the Italian CFL programme on the job opportunities for the youths'. In: Fornero, E., Castellino, O. (eds.) Pension Policy in an Integrating Europe. Edward Elgar, Cheltenham (2002)

Heckman, J., Ichimura, H., Todd, P.: Matching as an econometric evaluation estimator. Rev. Econ. Studies 64, 605-654 (1998)

Kluve, J.: The effectiveness of European active labor market policy. IZA Discussion Paper No. 2018. Bonn (2006)

Kluve, J., Schmidt, C.M.: Can training and employment subsidies combat European unemployment? Econ. Policy 35, 411-448 (2002)

ILO: Youth pathways to decent work. Report VI, International Labour Conference, 93rd Session, Geneva (2005)

Nikell, S.J., Bell, B.: Would Cutting Payroll Taxes on the Unskilled have a Significant Impact on Unemployment? In: de la Dehesa, G., Snower D.J. (eds.) Unemployment Policy, ch. 10, pp. 296-328 Cambridge University Press (1997)

OECD: Taxing wages 2004-2005. OECD, Paris (2006)

O'Higgins, N.: The challenge of youth unemployment. ILO, Employment and training papers, No. 7. Geneva (1997)

Rosenbaum, P.R., Rubin, D.B.: The central role of the propensity score in observational studies for causal effects. Biometrika 70(1), 41-55 (1983)

Saint-Paul, G.: Why are European countries diverging in their unemployment experience? J. Econ. Perspectives 18, 49-68 (2004)

Tattara, G., Valentini, M.: Job flows, worker flows in Italian manufacturing, 1982-1996. Paper presented at the EALE meeting. Lisbon (2004)

Giuseppe Tattara is professor of economics at the University of Venice. He has written extensively on economic development, industrial economics, labour economics and economic history. His contributions are published in important international journals (http:// econpapers.repec.org/RAS/pta153.htm).

e-mail: tattara@unive.it

Marco Valentini, Ph.D. in economics, has published several articles on labour economics and is now senior research officer at Tolomeo srl. (Treviso). 